\title{
An examination of the relationship between experimental climate and dimensions of the creative organization
}

\author{
Maja Strugar Jelača \\ University of Novi Sad, Faculty of Economics in Subotica, Subotica, Serbia \\ Radmila Bjekić \\ University of Novi Sad, Faculty of Economics in Subotica, Subotica, Serbia \\ Marko Aleksić \\ University of Novi Sad, Faculty of Economics in Subotica, Subotica, Serbia \\ Nemanja Berber \\ University of Novi Sad, Faculty of Economics in Subotica, Subotica, Serbia
}

\begin{abstract}
Today's business environment imposes the need to continuously generate creative ideas not only for companies to grow, but also to survive in a hypercompetitive environment. Forming a creative model of organization and stimulating employees' creative behavior is one of the priorities, which can be achieved by establishing a parallel organizational culture and a creative climate. So far, some authors have identified these two terms as equal, while others emphasize the need for their separation. The paper indicates the differences in understanding of organizational culture on the one hand and climate on the other.

The subject of the research is reflected in the analysis of the factors of importance for the formation of a creative organization. The paper aims to determine whether or not there is a positive relationship between the experimental climate and the dimensions that describe a creative organization model with a focus on organizational culture.

The research hypotheses were generated and empirically analyzed based on a survey conducted on a sample of 145 employees in organizations in the territory of the Republic of Serbia. The survey was developed by combining two methodologies formulated by G. Ekwall, "Creative Climate Model," and T. Amabile, "Organizational Creativity Model." Statistical methods, such as correlation analysis and analysis of variance, ANOVA, were applied in the paper.

The obtained results indicate that there is a positive statistically significant relationship between all three dimensions of creative organizational culture, such as flexible management system, motivation for greater achievements and freedom to use resources to form an experimental climate in the organization. Furthermore, by applying ANOVA, it was found that there was a statistically significant difference in the degree of experimental climate prevailing in the organization depending on its size, while no statistically significant difference between the organizations depending on their legal form was confirmed.

Finally, the paper highlights management measures to encourage the creation of a creative work environment.
\end{abstract}

\section{Keywords}

experimental climate, creative organizational culture, correlation, ANOVA

\section{Introduction}

Innovations are based on knowledge and they lead to the greater market share and penetration on new markets (Veselinović \& Veselinović, 2019), and overall growth and survival of the company
(Janković \& Golunović, 2019). Different perspectives in the analysis of innovations are increasingly preoccupying the scientific public in order to propose possible empirical relations and, based on those, set practical management tips. Great importance lies on the analysis of 
innovations from the point of view of organizational effectiveness (Glisson, 2015), which is one of the ways to achieve sustainable competitive advantage in a hypercompetitive business environment.

Employees at all levels should be motivated to apply a creative mindset that needs to be transformed into tangible innovative outputs. The aforementioned is possible by designing a creative organizational culture that employees will perceive as open to new ideas, creative behavior and innovation, and perceive it as an experimental organizational climate. This statement arises from the proven influence of organizational culture on the behavior and performance of employees (Giri \& Kumar, 2007) especially innovative ones (Glisson, 2015).

When analyzing the innovative potential of a company, it is not enough to take into account only organizational culture or organizational climate, but they should be analyzed together. The mentioned approach to the research of organizational variables will enable a concise and objective description of the organization's business. Research of the creative organizational culture as a separate concept can lead to blurred results if the employees do not perceive culture as creative and innovation-oriented, which means that they will resist certain procedures, so in the end, their innovative result will be absent. The aforementioned influenced the formulation of the research idea and the research framework aimed at the analysis of the elements of organizational culture and the characteristics of innovation oriented organizational climate. Thus, the subject of the research is the analysis of the relationship between creative organizational culture and experimental organizational climate that was perceived as such by the employees. Within the paper, the focus is set on the research of organizational procedures as inputs that encourage innovative behavior of employees, and not on the final result, i.e. achieving innovative performance, that is, an analysis of the organizational context that will enable creative and innovative results in the near future. This research focus arises from the assumption of the authors Schneider, Ehrhart \& Macey (2013), who believe that employees who perceive an organization as an entity that promotes equality, trust, ethics, and diversity lead to the achievement of strategic results by the employees, who are of great value to the company. The research aims to analyze the relationship between characteristics of a flexible management system, a motivational system aimed at incremental or radical changes, and the level of freedom to use company's resources that form creative organizational culture on the one hand and employees' perceptions of the work environment on the other. Also, in addition to the primary goal of the research, the secondary goal was identified, reflecting in the analysis of whether there is a difference between employees' perception of the work environment from the point of view of creativity and innovation, i.e. the experimental climate on the one hand, or, on the other hand, whether the employees work in companies registered as limited liability companies, joint-stock companies or public companies.

\section{Organizational culture and organizational climate in function of creativity and innovation}

In most research papers until the end of the 1990s, the terms organizational culture and organizational climate were considered equal (Glisson, 2015), while in the period after their difference became evident and a separate research begins.

Organizational culture consists of basic assumptions, expectations, and norms on which the company's business is based, i.e. it indicates how activities are performed within the organization. Through the elements mentioned, organizational culture influences behavior of the employees and their perception of work environment (Ali \& Patnaik, 2014, p. 7). A large number of authors in their studies emphasize the influence of organizational culture on the organizational climate (Aarons \& Sawitzky, 2006a).

Organizational climate is the perception of employees about the company in which they work (Ali \& Patnaik, 2014). It can be said that organizational climate is the perception of employees about their work environment depending on values, policies, procedures at the company level, management that defines, implements, and delegates those as well as practical tasks performed daily by each employee. Therefore, organizational climate is an individual's psychological vision of the work environment burdened with subjectivity and therefore it varies from employee to employee. Thus, the direct influence of the organizational climate on employee satisfaction and therefore on their performance is evident (Giri \& Kumar, 
2007). For this reason, it is very important to monitor employees' perceptions of the work environment in order to determine the positive or negative impact on business performance.

Based on previously highlighted key characteristics of both organizational variables, their differences can be summarized, and those are reflected in the fact that organizational culture is a long-term, very stable research construct while organizational climate as a construct is more susceptible to changes in a shorter period. (Denison, 1996).

Therefore, organizational culture together with organizational climate has a combined impact on creativity and innovation so that formulated basic assumptions and norms have a role in encouraging creativity, while their implementation which is dependent on employees has an impact on the innovation degree (Isaksen \& Treffinger, 2004).

\subsection{Dimensions of organizational culture}

The term organizational culture has been explored as a construct consisting of different elements. Although there is a range of different research on this topic, there are many similarities and overlaps within the identified elements or factors. An overview of the elements of organizational culture used in the research by different authors in different periods is shown in the following table.

Table 1 Possible elements of organizational culture

\begin{tabular}{l|l|l}
\hline Authors & Year & $\begin{array}{l}\text { Different elements of } \\
\text { organizational culture }\end{array}$ \\
\hline $\begin{array}{l}\text { Amabile, } \\
\text { Conti, Coon, } \\
\text { Lazenby \& } \\
\text { Herron }\end{array}$ & 1996 & $\begin{array}{l}\text { encouraging creativity, freedom, } \\
\text { resources, pressure, } \\
\text { organizational barriers to } \\
\text { creativity }\end{array}$ \\
\hline $\begin{array}{l}\text { Tesluk, Farr, } \\
\text { Klein }\end{array}$ & 1997 & $\begin{array}{l}\text { highlighting goals, emphasizing } \\
\text { purpose, reward orientation, task } \\
\text { support, social-emotional support }\end{array}$ \\
\hline $\begin{array}{l}\text { Cameron \& } \\
\text { Quinn }\end{array}$ & 1999 & $\begin{array}{l}\text { dominant characteristics, strategic } \\
\text { focus, employee management, } \\
\text { leadership style, success criterion }\end{array}$ \\
\hline $\begin{array}{l}\text { Glisson, } \\
\text { Green \& } \\
\text { Williams }\end{array}$ & 2012 & $\begin{array}{l}\text { professionalism (knowledge), } \\
\text { rigidity, resistance }\end{array}$ \\
\hline $\begin{array}{l}\text { Sharifirad \& } \\
\text { Ataei }\end{array}$ & 2012 & $\begin{array}{l}\text { involvement, consistency, } \\
\text { adaptability, mission }\end{array}$ \\
\hline $\begin{array}{l}\text { Amiri, } \\
\text { Haghgooyan, } \\
\text { \& Mohammadi }\end{array}$ & 2014 & $\begin{array}{l}\text { contribution, emphasis on } \\
\text { freedom, effective interaction }\end{array}$ \\
\hline $\begin{array}{l}\text { Iljins, } \\
\text { Skvarciany, \& } \\
\text { Gaile-Sarkane }\end{array}$ & 2015 & $\begin{array}{l}\text { adaptability, consistency, } \\
\text { employee satisfaction, mission, } \\
\text { involvement }\end{array}$ \\
\hline & & \\
\hline
\end{tabular}

Source: The authors
Observing previous research, we come across different ways of constructing the variable organizational culture. Thus, there is no single methodology when analyzing organizational culture (Schneider, Ehrhart \& Macey, 2013). When defining the construct of creative organizational culture, we were guided by the guidelines of authors Schneider, Ehrhart \& Macey (Schneider, Ehrhart \& Macey, 2011), who emphasize that employees' perception of work environment is most influenced by policies, practices, and procedures that guide their behavior and expectations and rewards for their results. The research uses three elements important for employees' perception of the work environment, i.e. for forming opinions about the organizational climate. The first element of a creative organizational culture is a flexible management system that encompasses a sum of management policies, management practices, and procedures. Another element is the system of motivation, i.e. support and rewards for achieved innovative achievements. The third element of organizational culture is the freedom to use resources, i.e. the possibility to put creative ideas into action. A flexible management system as an element that describes a creative organizational culture is indispensable in order to keep pace with the change. Therefore, many researchers call on companies to implement an organizational culture that is flexible and adaptive (Sarros, Cooper \& Santora, 2008) which is possible by establishing an appropriate management system that advocates the aforementioned principles. Emphasis is placed on the analysis of the appropriate leadership style which is a symbol of the formation of a new organizational culture (Bass, 1999; Giberson, Resick, Dickson, Mitchelson, Randall, \& Clark, 2009). On the other hand, the appropriate leadership style greatly affects the level of employees' creativity and the degree of innovation at the company level. Through their power, leaders influence employees' behavior, direct the decision-making process and directly influence the choice of an optimal decision on the one hand, while on the other they have a great responsibility for the achieved business performance. Thus, one of the ways to implement a flexible management system is application of a transformational leadership style to motivate employees to be creative and innovative (Majeed, Ramaya, Mustamil, Nazri, \& Jamshed, 2007). Many authors advocate the importance of openness of superiors for implementing 
innovations suggested by everyone in the organization, which leads to innovative behavior and organizational innovation (Elenkov \& Manev, 2005; Jung, Chow, \& Wu, 2003). Such a leadership style, in order to be in the function of forming a creative organizational culture, should provide a guiding vision, intellectual stimulation, provide support to employees, have high expectations in terms of performance, be an appropriate role model and encourage acceptance (Sarros et al., 2008, p. 152). Furthermore, in addition to implementing a transformational leadership style, a flexible management system that should serve to reach a higher level of creativity and innovation should encourage leaders to the following patterns of behavior: stimulation to find new knowledge, further diffusion of tacit knowledge through multiple communication channels, creating the role of innovative leader as role models for all employees, providing an innovative and inspiring vision that motivates all employees to focus joint efforts on its joint implementation (De Jong \& Den Hartog, 2007).

Today, creative organizational culture must be formed so that dissemination and implementation of new knowledge is not a challenge, but a necessity. In this process, there is a set of different factors that influence the creation of such a culture, in addition to a flexible management system that should enable and support this process, i.e. to set norms and values that indicate that employees can conduct experimental analyzes, take risks, and make mistakes (Amabile et al., 1996); the second factor is motivation and rewards (Dixit \& Nanda, 2011) of employees to implement innovative activities. As part of motivation, emphasis is placed on rewards for employees' creative thinking and their creative performance, which indicates that they will continue to be creative in performing other business tasks (Eisenberger \& Armeli, 1997). Therefore, within the work, the emphasis is placed on motivating employees to greater achievements that will have a creative and innovative nature. The last element within the organizational culture is the freedom to use resources necessary for successful and efficient implementation of new ideas through projects (Amabile et al., 1996). If it is not difficult to get the necessary resources, the perception of employees is that their idea is supported, delegated project task is important, which affects their satisfaction and sense of importance and strong belonging to the company, which directly leads to greater energy and commitment. Freedom to use resources implies the possibility of using financial funds and material resources for new projects (Moultrie \& Young, 2009). Also, freedom to use resources implies flexibility and a multidisciplinary approach in human resources engagement. Furthermore, freedom to use resources implies flexibility and a multidisciplinary approach in the engagement of human resources. In order to have positive effects when engaging all resources, it is necessary to ensure a free and transparent flow of information, as one of the most important resources today.

\subsection{Dimensions of organizational climate}

The organizational climate or perception of employees about the work environment has a significant impact on creative and innovative output of employees (Glisson, 2015; Mayfield \& Mayfield, 2010, p. 162). Therefore, the emphasis is on forming an innovative organizational climate with a focus on establishing a cooperative atmosphere that will lead to more frequent social interactions between employees (Chen \& Huang, 2007) which will cause flow of a larger information base, different ideas and influence the transfer and formation of new knowledge. If the organizational climate is characterized as innovative and cooperative, it will give clear signals to employees that they need to network and establish new knowledge networks, while if the organizational climate is not characterized as such, the interaction between the employees will be sabotaged and the flow of new knowledge and ideas will stop (Chen \& Huang, 2007) and that will lead to less creativity and lack of innovative results. Thus, individual elements of the organizational climate affect the establishment of differences between companies that are classified as innovative and promising on the one hand and non-innovative or stagnant companies on the other hand as measured by the nature of business strategy, success in transforming creative ideas into new products that are successfully commercialized in the market, the level of company's originality viewed through technical and market analysis as well as the number of implemented patents (Ekvall, 1996). The mentioned relation indicates the need of companies to create an experimental organizational climate that is creatively oriented and which employees perceive as open and easily accept it. In such a business ecosystem, the 
creative commitment of employees and their innovative output would lead to growth of innovation at the company level, which is one of the preconditions for the survival of the company (Janjić \& Rađenović, 2019) in a dynamic market environment.

The creative climate in a company is manifested through an organizational culture that leads to creative results of its employees (Ekvall, 1996). This author emphasizes ten factors that influence creation of a creative climate, and they are: challenge, freedom, support to ideas, openness, dynamism, humor, debate, conflict, risk acceptance and available time for ideas. Factors can be described as follows (Pörzse, Takacs, Csedo, Berta, Sara \& Fejes, 2012):

1. Challenge means that employees are satisfied with their job, that they are fulfilled in the workplace and thus include maximum energy;

2. Freedom means the possibility of independent performance of tasks, free flow of information and independent decision-making;

3. Idea support means that the company's management supports implementation of great ideas while other employees are ready to listen to each other about new initiatives;

4. Openness is a kind of freedom and feeling of employees to be able to propose their ideas, to test them and if mistakes are made not to be punished;

5. Dynamism indicates a turbulent work environment in which something is constantly happening;

6. The humor factor means a relaxed work environment in which laughter and positive attitude are often heard;

7. Debate means accepting different views, opinions, and perspectives whose combinations lead to defiance of the status quo situation;

8. Conflicts are a factor that is inversely related to the creative organizational climate, so a work environment full of negative comments and conflicts is not desirable;

9. Risk acceptance is necessary if a new idea needs to be implemented for the first time in the organization;

10. The time available for ideas should be as long as possible so that employees can exchange ideas that are not planned in advance, but are the result of incoming, sudden impulses from the external environment.

\section{Research methodology}

Based on the studied theoretical base, research hypothesis $\mathrm{H} 1$ is set: There is a positive statistically significant correlation between elements of creative organizational culture such as flexible management system, motivation for greater achievements, and freedom to use resources and experimental organizational climate. The authors Iljins, Skvarciany \& GaileSarkane (Iljins et al., 2015) also emphasize the growing need for the analysis of the mentioned correlation in the modern business environment. Within the study conducted by these authors, they point out the existence of a statistically significant positive relationship between organizational culture and organizational climate, namely the following cultural factors: stability, reward system, job satisfaction, team orientation, support, key values and agreement (p. 949). These factors are components of the elements of organizational culture such as consistency, satisfaction, and involvement that most influence the organizational climate. The necessity of analyzing the relationship between the mentioned variables and their joint observation is also indicated by the results of a study that confirms that organizational culture through organizational climate influences employees' approach to work (Aarons \& Sawitzky, 2006b). Also, a large number of authors in their research have proven the direct influence of either organizational culture or organizational climate on the achievement of creative and innovative performances (Halim, Ahmad, Ramayah, \& Hanifah, 2014; Hogan \& Coote, 2014; $\mathrm{Yu}, \mathrm{Yu} \& \mathrm{Yu}, 2013)$. It is therefore necessary to determine which elements of organizational culture have the greatest impact on favorable perception of employees and thus form an experimental organizational climate that encourages creative behavior of employees and the achievement of innovative results. Since the experimental organizational climate influences the achievement of creative and innovative results, in the empirical research we tried to determine whether there is a difference in employees' perception in the following: whether the organizational climate is experimental or not depending on the legal structure of the company and the company's size. We took into account the parameter of the organization's size because there 
is no unique opinion on innovativeness of large organizations. Nowadays it is important to encourage large companies, as the "national champions", which employ large numbers of workers (Ciutacu, \& Chivu, 2015), to be innovatively oriented. While one group of authors believe that large companies have larger financial funds at their disposal and can take higher risk, which can lead to greater innovation (Aranda, Rata, \& Duarte, 2001), other authors believe that large companies are problematic in implementing innovations (Dougherty, 1992) because they are less flexible and burdened with bureaucracy, unlike small and medium sized organizations. Furthermore, in the Republic of Serbia, public companies are often criticized for being noninnovative and as such do not have a represented or creative organizational culture, and therefore no experimental organizational climate. The degree of innovation of public organizations largely depends on institutional factors (Painter, 2005). Based on the highlighted assumptions, hypothesis $\mathrm{H} 2$ is set: There is a statistically significant difference in the level of application of the experimental organizational climate depending on whether the company is large, medium, or small. Hypothesis $\mathrm{H} 3$ reads: There is a statistically significant difference in the level of application of the experimental organizational climate depending on the legal form of the company.

To conduct empirical research, a combination of two proven and generally accepted methodologies was used. A questionnaire, "Model of organizational creativity" developed by Amabile (Amabile, 1996) was used, as well as a questionnaire set by Ekval (Ekvall, 1996) entitled "Model of creative climate". Modified questionnaire forms were used, their revised version consisting of 29 questions. The research was conducted on a sample of 145 employees in organizations on the territory of the Republic of Serbia.

Table 2 Descriptive statistics of respondents

\begin{tabular}{l|r|r}
\hline & Frequency & Percent \\
\hline Gender & 69 & \\
Male & 76 & 47.6 \\
Female & 145 & 52.4 \\
In total & & 100.0 \\
\hline Age & 37 & \\
Less than 30 years & 73 & 25.5 \\
30-50 & 35 & 50.3 \\
Over 50 years & 145 & 24.1 \\
In total & & 100.0 \\
\hline
\end{tabular}

\begin{tabular}{l|r|r}
\hline Level of Education & & \\
High school & 15 & 10.3 \\
Higher education & 26 & 17.9 \\
High & & \\
education/university & 98 & 67.6 \\
Missing & 6 & 4.1 \\
In total & 145 & 100.0 \\
\hline
\end{tabular}

Source: The author's calculation

Using factor analysis, new factors have been identified that are in line with the tested sample in the territory of the Republic of Serbia (Strugar Jelača, Bjekić \& Leković, 2018). New factors are elements of organizational culture and organizational climate. Organizational culture consists of three newly defined factors, namely Flexible Management System, which includes 8 questions, the element of Motivation for Higher Achievement, which includes 3 questions, and the element of Freedom to Use Resources, which also includes 3 questions. The dependent variable is the Experimental Organizational Climate, which consists of three factors that describe employees' perceptions of acceptance of diversity, experimental expression, and support for ideas. The dependent variable includes 15 questions.

\section{Research results}

Pearson's correlation analysis was used to analyze the hypothesis X1, which reads: There is a positive statistically significant correlation between elements of creative organizational culture such as flexible management system (FMS), motivation for greater achievements (MGA) and freedom to use resources (FUR) and experimental organizational climate (EOC). The results of the correlation analysis are shown in Table 3.

Table 3 Correlation analysis between elements of organizational culture and experimental organizational

\begin{tabular}{c|l|l|l|l}
\multicolumn{5}{c}{ climate } \\
$\begin{array}{c}\text { Correlation } \\
\text { analysis }\end{array}$ & FMS & MGA & FUR & EOC \\
\hline FMS r & 1 & & & \\
Sig. & & & & \\
\hline MGA r &, $226^{* *}$ & 1 & & \\
Sig. &, 006 & & & \\
\hline FUR r &, $199^{*}$ &, $438^{* *}$ & 1 & \\
Sig. &, 016 &, 000 & & \\
\hline EOC r &, $501^{* *}$ &, $\mathbf{5 1 3 ^ { * * }}$ & $\mathbf{, 5 2 6 ^ { * * }}$ & 1 \\
Sig. &, 000 &, 000 &, 000 & \\
\hline \multicolumn{5}{|c}{ Source: The author's calculation }
\end{tabular}

The results of correlation analysis indicate that there is a statistically significant correlation between all the elements of creative 
organizational culture and experimental organizational climate. Thus, there is a statistically significant positive correlation of high strength between flexible management system in the company and the perception of employees of the organizational climate as experimental ( $\mathrm{r}=$ $.501, \mathrm{p}=.000)$; motivation of employees to implement greater achievements and perception of the work environment as experimentally oriented or experimental organizational climate $(\mathrm{r}=.513, \mathrm{p}$ $=.000) ;$ freedom to use resources during realization of the new ideas and tasks on the one hand and the experimental organizational climate on the other hand $(\mathrm{r}=.526, \mathrm{p}=.000)$. In the end, it can be concluded that the set hypothesis $\mathrm{H} 1$ is proven.

The analysis of variance was done to test hypothesis H2, which reads: There is a statistically significant difference in the level of application of experimental organizational climate depending on the size of the company. During the analysis of variance, the Homogeneity Test was violated, so the Welch test was performed, shown in the following table.

Table 4 Welch test

\begin{tabular}{l|l|l|l|l}
\hline & Statistic & df1 & df2 & Sig. \\
\hline Welch & 3,399 & 2 & 29,431 &, 047 \\
\hline \multicolumn{4}{c}{ Source: Author's calculation }
\end{tabular}

Table 5 Evaluation of the experimental organizational climate depending on the size of the organization

\begin{tabular}{l|l|l|l|l}
\hline & $\mathbf{N}$ & Mean & SD & Std. Error \\
\hline Medium (M) & 55 & 3,5018 &, 60748 &, 08191 \\
Large (L) & 78 & 3,2547 &, 84837 &, 09606 \\
Small (S) & 12 & 3,8944 &, 94984 &, 27419 \\
Total & 145 & 3,4014 &, 79242 &, 06581 \\
\hline
\end{tabular}

Table 6 Multiple comparisons

\begin{tabular}{|c|c|c|c|c|c|c|}
\hline \multirow[t]{2}{*}{ I } & \multirow[t]{2}{*}{$\mathrm{J}$} & \multirow{2}{*}{$\begin{array}{l}\text { Mean } \\
\text { differen. }\end{array}$} & \multirow{2}{*}{$\begin{array}{l}\text { Std. } \\
\text { Error }\end{array}$} & \multirow{2}{*}{ Sig. } & \multicolumn{2}{|c|}{$\begin{array}{l}\text { 95\% Confidence } \\
\text { Interval }\end{array}$} \\
\hline & & & & & $\begin{array}{l}\text { Lower } \\
\text { Bound }\end{array}$ & $\begin{array}{l}\text { Upper } \\
\text { Bound }\end{array}$ \\
\hline$M$ & $\begin{array}{l}L \\
S\end{array}$ & $\begin{array}{l}, 24712 \\
-39263\end{array}$ & $\begin{array}{l}, 13644 \\
24690\end{array}$ & $\begin{array}{l}170 \\
253\end{array}$ & $\begin{array}{l}-, 0761 \\
-, 9774\end{array}$ & $\begin{array}{l}, 5703 \\
, 1922\end{array}$ \\
\hline $\mathrm{L}$ & $\begin{array}{l}M \\
\mathrm{~S}\end{array}$ & $\begin{array}{l}-, 24712 \\
-, 63974^{*}\end{array}$ & $\begin{array}{l}13644 \\
, 24029\end{array}$ & $\begin{array}{l}170 \\
, 023\end{array}$ & $\begin{array}{l}-, 5703 \\
-1,2089\end{array}$ & $\begin{array}{l}0,0761 \\
-.0706\end{array}$ \\
\hline$S$ & $\begin{array}{l}M \\
L\end{array}$ & $\begin{array}{l}, 39263 \\
, 63974^{*}\end{array}$ & $\begin{array}{l}\text {,24690 } \\
\text {,24029 }\end{array}$ & $\begin{array}{l}, 253 \\
, 023\end{array}$ & $\begin{array}{l}-, 1922 \\
, 0706\end{array}$ & $\begin{array}{l}, 9774 \\
1,2089\end{array}$ \\
\hline
\end{tabular}

The conducted analysis of variance indicates that there is a statistically significant difference $(\mathrm{F}$ $(4,626)=5,112, p=.016)$ between the companies depending on the size and the degree of their experimental organizational climate. The application of the Tukey post hoc test indicates that the difference is statistically significant only between small and large organizations based on application of experimental organizational climate. Thus, small organizations (Mean = 3.8944; SD $=.94984$ ) have a higher level of experimental organizational climate compared to large organizations (Mean $=3.2547 ; \mathrm{SD}=$ .84837). We can conclude that hypothesis $\mathrm{H} 2$ is accepted.

Table 7 presents an analysis of variance to test Hypothesis H3, which reads: There is a statistically significant difference in the level of application of experimental organizational climate depending on the legal form of the company.

Table 7 ANOVA

\begin{tabular}{l|l|l|l|l|l}
\hline & $\begin{array}{l}\text { Sum of } \\
\text { squares }\end{array}$ & df & $\begin{array}{l}\text { Mean } \\
\text { square }\end{array}$ & F & Sig. \\
\hline $\begin{array}{l}\text { Between } \\
\text { Groups }\end{array}$ & 2,968 & 3 &, 989 & 1,595 &, 193 \\
\hline $\begin{array}{l}\text { Within } \\
\text { Groups }\end{array}$ & 87,454 & 141 &, 620 & & \\
\hline Total & 90,422 & 144 & & & \\
\hline
\end{tabular}

The presented model is not significant because the significance is greater than 0.05 , which indicates that hypothesis $\mathrm{H} 3$ is not accepted and that there is no statistically significant difference in the level of experimental organizational climate depending on whether the employee works in a joint-stock company, limited liability company or a public company.

\section{Conclusion}

The results of the conducted empirical research indicate that in companies on the territory of the Republic of Serbia employees who want to emphasize their creative nature and thus contribute to greater innovation at the level of the entire company, give priority to a flexible management system, a motivation system that recognizes creative effort which leads to incremental and radical changes and free flow of necessary resources needed for implementation of innovative projects. If the organizational culture of the company is based on the mentioned business norms, the employees perceive such a working environment as innovative and creatively oriented, i.e. they evaluate it as an experimental organizational climate. Furthermore, in the companies on the territory of the Republic of Serbia there is a different perception of employees about the work environment from the point of view of creativity and innovation, depending on 
whether they work in small or large companies. Employees working in small companies characterized the organizational climate as experimentally oriented, in contrast to the employees working in large ones, where they do not perceive organizational climate as experimentally oriented. These empirical results indicate that greater creative commitment can be expected, as well as the ultimate innovative results within small companies in the territory of the Republic of Serbia. On the other hand, in larger companies there is often a lack of creative engagement of employees and thus innovative results. The observed situation about the lack of innovative incentives within large companies should be taken into account and the definition of measures that will affect the change of organizational climate in large companies should begin. This statement is very important because within the economic environment of the Republic of Serbia there is a great number of large companies, whose encouragement of innovative activities would lead to better results at the level of the entire economy.

The obtained results indicate a proposal of business principles that companies (both small, medium, and large), should apply within their businesses for the employees to emphasize their creative behavior and achieve innovative performance. This makes it easier for companies to operate successfully in a highly turbulent and hypercompetitive market by offering innovation before the others.

The theoretical and empirical part of the paper leads to several contributions: in theoretical and research sense, the importance of separating two research variables, such as organizational climate and organizational culture, which are often identified, is emphasized; concerning further research on this topic, new research elements within the variable organizational climate have been identified; and further, a new research variable called experimental organizational climate was formed.

The shortcomings of the conducted research are reflected in the sample size, a territorial connection of the research, and one-time dimension. The proposal for future research is to conduct the same research within the economic environment of the bordering countries to the Republic of Serbia to conduct a comparative analysis. In that way, innovative potential of the company in the countries close to Serbia would be determined, which would enable the transfer of good practice in order to improve innovative activity of our companies. Also, the research could be conducted in two time periods, i.e. before changing the elements of organizational culture and after introduction of the proposed measures to establish an innovative oriented organizational culture and on that basis the newly formed perception of the organizational climate by the employees.sm

\section{References}

Aarons, G. A., \& Sawitzky, A. C. (2006). Organizational climate partially mediates the effect of culture on work attitudes and staff turnover in mental health services. Administration and policy in mental health and mental health services research, 33 (3), 289-301. https://doi.org/10.1007/s10488-006-0039-1

Aarons, G. A., \& Sawitzky, A. C. (2006). Organizational culture and climate and mental health provider attitudes toward evidence-based practice. Psychological Services, 3 (1), 61-72. https://doi.org/10.1037/1541-1559.3.1.61

Ali, A., \& Patnaik, B. (2014). Influence of organizational climate and organizational culture on managerial effectiveness: An inquisitive study. The Carrington Rand Journal of Social Sciences, 1 (2), 1-20.

Amabile, T. (1996). Creativity in Context: Update to the Social Psychology of Creativity. CO: Westview Press, Boulder.

Amabile, T. M., Conti, R., Coon, H., Lazenby, J., \& Herron, M. (1996). Assessing the work environment for creativity. Academy of management journal, 39 (5), 1154-1184. https://doi.org/10.2307/256995

Amiri, A., Haghgooyan, Z., \& Mohammadi, F. (2014). Identifying and Prioritizing affecting Components on Creative Organizational Culture. International Journal of Academic Research in Economics and Management Sciences, 3 (5), 53-68. https://doi.org/10.6007/IJAREMS/v3-i5/1142

Aranda, D. A., Rata, B. M., \& Duarte, A. R. (2001). Innovation and firm size: An empirical study for Spanish engineering consulting companies. European Journal of Innovation Management, 4 (3), 133-142. https://doi.org/10.1108/EUM0000000005671

Bass, B. M. (1999). Two decades of research and development in transformational leadership. European Journal of Work and Organizational Psychology, 8 (1), 9-32. https://doi.org/10.1080/135943299398410

Cameron, K. S., \& Quinn, R. E. (1999). Diagnosing and Changing Organizational Culture. Based on the Competing Values Framework. MA: Addison-Wesley, Reading.

Chen, C. J., \& Huang, J. W. (2007). How organizational climate and structure affect knowledge management the social interaction perspective. International journal of information management, 27(2), 104-118. https://doi.org/10.1016/j.ijinfomgt.2006.11.001

Ciutacu, C., \& Chivu, L. (2015). Romania's Deindustrialisation. From the "Golden Age" to the "Iron Scrap Age". Procedia Economics and Finance, 22, 209215. https://doi.org/10.1016/S2212-5671(15)00264-6 
De Jong, J. P. J., \& Den Hartog, D. N. (2007). How leaders influence employees' innovative behaviour. European Journal of Innovation, 10, 41-64. https://doi.org/10.1108/14601060710720546

Denison, D. R. (1996). What is the difference between organizational culture and organizational climate? A native's point of view on a decade of paradigm wars. Academy of Management Review, 21, 619-654. https://doi.org/10.5465/amr.1996.9702100310

Dixit, G. K., \& Nanda, T. (2011). Strategic alignment of organizational culture and climate for stimulating innovation in SMEs. International Journal of Innovation, Management and Technology, 2 (1), 77-85.

Dougherty, D. (1992). Interpretive barriers to successful product innovation in large firms. Organization science, 3 (2), 179-202.

https://doi.org/10.1287/orsc.3.2.179

Eisenberger, R., \& Armeli, S. (1997). Can silent reward increase creative performance without reducing intrinsic creative interest? Journal of Personality and Social Psychology, 72 (3), 652-663. https://doi.org/10.1037/0022-3514.72.3.652

Ekvall, G. (1996). Organizational climate for creativity and innovation. European journal of work and organizational psychology, 5 (1), 105-123. https://doi.org/10.1080/13594329608414845

Elenkov, D. S., \& Manev, I. M. (2005). Top management leadership and influence on innovation: The role of sociocultural context. Journal of Management, 31 (3), 381-402. https://doi.org/10.1177/0149206304272151

Giberson, T. R., Resick, C. J., Dickson, M. W., Mitchelson, J. K., Randall, K. R., \& Clark, M. A. (2009). Leadership and organizational culture: Linking CEO characteristics to cultural values. Journal of Business and Psychology, 24 (2), 123-137. https://doi.org/10.1007/s10869-009-9109-1

Giri, V.N., \& Kumar, B.P. (2007). Impact of organizational climate on job satisfaction and job performance. Psychological Studies, 52 (2), 155-168.

Glisson, C. (2015). The role of organizational culture and climate in innovation and effectiveness. Human Service Organizations: Management, Leadership \& Governance, 39 (4), 245-250. https://doi.org/10.1080/23303131.2015.1087770

Glisson, C., Green, P., \& Williams, N. J. (2012). Assessing the Organizational Social Context (OSC) of child welfare systems: implications for research and practice. Child Abuse Negl., 36 (9), 621-632. https://doi.org/10.1016/i.chiabu.2012.06.002

Halim, H. A., Ahmad, N. H., Ramayah, T., \& Hanifah, H. (2014). The growth of innovative performance among SMEs: Leveraging on organisational culture and innovative human capital. Journal of Small Business and Entrepreneurship Development, 2 (1), 107-125.

Hogan, S. J., \& Coote, L. V. (2014). Organizational culture, innovation, and performance: A test of Schein's model. Journal of Business Research, 67(8), 16091621.

https://doi.org/10.1016/j.jbusres.2013.09.007

Iljins, J., Skvarciany, V., \& Gaile-Sarkane, E. (2015). Impact of organizational culture on organizational climate during the process of change. Procedia-Social and Behavioral Sciences, 213, 944-950. https://doi.org/10.1016/j.sbspro.2015.11.509
Isaksen, S. G., \& Treffinger, D. J. (2004). Celebrating 50 years of reflective practice: Versions of creative problem solving. Journal of Creative Behavior, 38, 75101.

https://doi.org/10.1002/j.2162-6057.2004.tb01234.x

Janković, G., \& Golubović, M. (2019). Open innovation in small and medium-sized enterprises. Ekonomika, 65(3), 89-101. https://doi.org/10.5937/ekonomika1903089J

Janjić, I., \& Rađenović, T. (2019). The importance of managing innovation in modern enterprises. Ekonomika, 65(3), 45-54 https://doi.org/10.5937/ekonomika1903045J

Jung, D. I., Chow, C., \& Wu, A. (2003). The role of transformational leadership in enhancing organizational innovation: Hypotheses and some preliminary findings. Leadership Quarterly, 14 (4-5), 525-544. https://doi.org/10.1016/S1048-9843(03)00050-X

Majeed, N., Ramaya, T., Mustamil, N., Nazri, M. \& Jamshed, S. (2017). Transformational Leadership and Organizational Citizenship Behavior: Modeling Emotional Intelligence as Mediator. Management and Marketing. Challenges for the Knowledge Society, 12 (4), 571-590. https://doi.org/10.1515/mmcks-2017-0034

Mayfield, M., \& Mayfield, J. (2010). Developing a scale to measure the creative environment perceptions: A questionnaire for investigating garden variety creativity. Creativity Research Journal, 22 (2), 162-169. https://doi.org/10.1080/10400419.2010.481511

Moultrie, J., \& Young, A. (2009). Exploratory study of organizational creativity in creative organizations. Creativity and Innovation Management, 18 (4), 299-314. https://doi.org/10.1111/j.1467-8691.2009.00536.x

Painter, C. (2005). Operating codes in the emerging system of local government: From 'top-down state' to 'disciplines pluralism'? Public Money \& Management, 25 (2), 89-98. https://doi.org/10.1111/j.1467-9302.2005.00458.x

Pörzse, G., Takacs, S., Csedö, Z., Berta, Z., Sara, Z., \& Fejes, J. (2012). The impact of creative organizational climate on the innovation activity of medical devices manufacturing firms in Hungary. European Journal of Business and Management, 4 (13), 1-11.

Sarros, J. C., Cooper, B. K., \& Santora, J. C. (2008). Building a climate for innovation through transformational leadership and organizational culture. Journal of Leadership \& Organizational Studies, 15 (2), $145-158$. https://doi.org/10.1177/1548051808324100

Sharifirad, M. S., \& Ataei, V. (2012). Organizational culture and innovation culture: exploring the relationships between constructs. Leadership \& Organization Development Journal, 33 (5), 494-517. https://doi.org/10.1108/01437731211241274

Schneider, B., Ehrhart, M. G., \& Macey, W. H. (2011). Perspectives on organizational climate and culture. In S. Zedeck (Ed.), APA handbooks in psychology ${ }^{\circledR}$. APA handbook of industrial and organizational psychology, Vol. 1. Building and developing the organization (pp. 373-414). American Psychological Association. https://doi.org/10.1037/12169-012 
Schneider, B., Ehrhart, M. G., \& Macey, W. H. (2013). Organizational Climate and Culture. Annual Review of Psychology, 64, 361-388.

https://doi.org/10.1146/annurev-psych-113011-143809

Strugar Jelača, M., Bjekić, R., \& Leković, B. (2018).

Evolution of methodology for organizational creativity:

An application in Serbia. 49th International Scientific Conference Quantitative Analysis in Economics (pp.

213-222). Niš: Faculty of Economics, University of Niš.

Tesluk, P. E., Farr, J. L, \& Klein, S. A. (1997). Influences of organizational culture and climate on individual creativity. Journal of Creative Behavior, 31(1), 27-41. https://doi.org/10.1002/j.2162-6057.1997.tb00779.x

\section{$\triangle$ Correspondence}

\section{Maja Strugar Jelača}

University of Novi Sad, Faculty of Economics in Subotica Segedinski put 9-11, 24000, Subotica, Serbia

E-mail: maja.strugar.jelaca@ef.uns.ac.rs
Yu, C., Yu, T. F., \& Yu, C. C. (2013). Knowledge sharing, organizational climate, and innovative behavior: A cross-level analysis of effects. Social Behavior and Personality: an international journal, 41 (1), 143-156. https://doi.org/10.2224/sbp.2013.41.1.143

Veselinović, N., \& Veselinović, M. (2019). Technological innovation in the petroleum industry: The case of NIS jsc Novi Sad. Economics of Sustainable Development, 3 (1), 19-28.

https://doi.org/10.5937/ESD1901019V 